The Bangladesh Veterinarian (2010) 27(1) : 18 - 25

\title{
Lactation performance of Red Chittagong Cattle and effects of environmental factors
}

\author{
M. A. Habib*, M. A. Afroz and A. K. F. H. Bhuiyan ${ }^{1}$ \\ Department of Animal Breeding and Genetics, Faculty of Animal Husbandry, Bangladesh \\ Agricultural University, Mymensingh 2202, Bangladesh
}

\begin{abstract}
The present study was undertaken to estimate effects of environmental factors on milk production traits in Red Chittagong Cattle (RCC). A total of 103 milk yield records of 45 RCC cows obtained between 2005 and 2009 were analysed. Actual lactation yield, lactation length, daily milk yield and dry period were estimated as $500.7 \pm 19.3 \mathrm{~kg}, 259.6 \pm$ 6.2 days, $1.9 \pm 0.1 \mathrm{~kg}$ and $162.4 \pm 7.7$ days, respectively. Age and season corrected lactation yield, 305 day milk yield and daily milk yield were estimated as $605.4 \pm 22.9$, $677.1 \pm 19.4$ and $2.2 \pm 0.1 \mathrm{~kg}$, respectively. Sex of calf and season of birth did not significantly $(\mathrm{P}>0.05)$ affect production, but lactation order significantly $(\mathrm{P}<0.05)$ affected production except lactation length. Year of birth had no effect $(\mathrm{P}>0.05)$ on the traits analysed except daily milk yield $(\mathrm{P}<0.05)$. Calving age significantly $(\mathrm{P}<0.05)$ affected lactation yield but did not other traits. Cows in $5^{\text {th }}$ lactation produced highest total (604.3 $\pm 69.3 \mathrm{~kg})$ and daily milk yield $(2.17 \pm 1.8 \mathrm{~kg})$. Cows aged $6-7$ years had best lactation yield (576.8 $\pm 60.5 \mathrm{~kg})$. (Bangl. vet. 2010. Vol. 27, No. 1, $18-25)$
\end{abstract}

\section{Introduction}

In the dairy industry, productive traits directly affect the profitability of the farm. These traits depend largely on the genetic potential of the dam and sire. Profitable breeding could be improved by keeping lactation length, dry period and service period between optimal limits (Alpan, 1994; Cilek and Tekin, 2005). In order to let an individual express its full genetic potential, it is necessary to optimize the environment. Some environmental factors can measured, such as age, year, season, milking frequency, but some cannot, such as disease. Although, data on performance of exotic and crossbred cows are available in Bangladesh, they are very limited in case of indigenous cattle. A comprehensive study on milk production traits of indigenous cattle is essential for improving the breeding efficiency and formulating breeding strategy. Red Chittagong Cattle (RCC) is a promising indigenous type with some unique features, and is found in Chittagong area. But they have been losing their unique features due to indiscriminate breeding with poor indigenous, exotic and crossbred cattle.

The present study was conducted to know the factors affecting milk production potential of RCC in intensive farm management conditions in Bangladesh.

* Correspondence E-mail :- ahsan.rony@yahoo.com 


\section{Materials and Methods}

Data on milk production of RCC cows were collected from the nucleus herd of Bangladesh Agricultural University (BAU) Dairy Farm, Mymensingh from 2005 to 2009. To determine the effect of season, the months were grouped into summer (March - June), rainy season (July - October) and winter (November - February). Generally, the animals were maintained in face-out open sheds. Bulls, lactating cows and calves were kept in separate sheds. Pregnant cows were usually moved to the maternity barns about two months before calving. Artificial insemination (AI) was practiced. Animals were stall-fed throughout and were seldom grazed. Ureamolasses-straw or molasses-straw were provided twice a day ad lib throughout. Green forage including German grass, sorghum and maize fodder were provided at 5 $\mathrm{kg} / \mathrm{animal} /$ day. Concentrate mixture (wheat bran, rice polish, corn powder, oil cake, soybean meal, di-calcium phosphate, salt and vitamin-mineral premix) was supplied each morning at $600 \mathrm{~g} /$ lactating cow, $500 \mathrm{~g} /$ pregnant cow and $400 \mathrm{~g} /$ dry cow and heifer. Calves remained in separate pens except at milking time when they were allowed to suck from their dams, until weaning. Cows were usually culled for old age, failure to produce milk or reproductive incapability. Replacements were usually selected from calves born in the herd. Cattle were regularly vaccinated against Foot and Mouth Disease and Anthrax. Adult animals were treated time to time with albendadole (Endokill ${ }^{\circledR}$ - ACI Ltd., Helmex ${ }^{\circledR}$ - Renata Animal Health Ltd.), tetramizole \& oxyclozanide (Tetranid ${ }^{\circledR}$ - Techno Drugs Ltd.; Levanid ${ }^{\circledR}$ - ACME Laboratories Ltd.) and ivermectin (Cevamec ${ }^{\circledR}$ - 1\% - ACI Ltd.), while fenbendazole (Peraclear ${ }^{\circledR}$ - Techno Drugs Ltd.) was used for young calves. All anthelmintics were administered according to the results of faecal sample examination. Milk yield, lactation length and dry period were measured. The test day milk yields were standardized according to age at calving and season of calving as described by Van Vleck and Henderson (1961).

\section{Data analysis and statistical model}

Simple means and standard errors for the traits studied were estimated using SPSS 11.5 computer package program. For analysis of variance (ANOVA), LSD test using SPSS program was used. Duncan's multiple range test (DMRT) was used for multiple comparisons of each trait. The statistical model was as follows:

\footnotetext{
$\mathrm{Y}_{\mathrm{ijk} k m n}=\mu_{\mathrm{i}}+\mathrm{A}_{\mathrm{ij}}+\mathrm{B}_{\mathrm{ik}}+\mathrm{C}_{\mathrm{il}}+\mathrm{D}_{\mathrm{im}}+\mathrm{E}_{\mathrm{in}}+\mathbf{e}_{\mathrm{ijk} k \mathrm{mn}}$

Where,

$\mathrm{Y}_{\mathrm{ijklmn}}=$ Observed milk production $\mathrm{i}$ at lactation number $\mathrm{j}$, calving age $\mathrm{k}$, calving season 1 , calving year $\mathrm{m}$ and sex of calf born $\mathrm{n}$,

$\mu_{\mathrm{i}} \quad=$ Population mean for trait $\mathrm{i}$,

$\mathrm{A}_{\mathrm{ij}} \quad=$ Fixed effects of lactation number $\mathrm{j}$ for trait $\mathrm{i}(\mathrm{j}=1,2, \ldots, 6)$,

$\mathrm{B}_{\mathrm{ik}}=$ Fixed effects of calving age $\mathrm{k}$ for trait $\mathrm{i}(\mathrm{k}=<4,4-5,5-6,6-7$ and $\geq 7$ years),

$\mathrm{C}_{\mathrm{il}}=$ Fixed effects of calving season 1 for trait $\mathrm{i}(\mathrm{l}=$ summer, rainy, winter $)$,

$\mathrm{D}_{\mathrm{im}}=$ Fixed effects of calving year $\mathrm{m}$ for trait $\mathrm{i}(\mathrm{m}=2005,2006, \ldots, 2009)$,
} 
$\mathrm{E}_{\text {in }}=$ Fixed effects of sex of calf born $\mathrm{n}$ for trait $\mathrm{i}(\mathrm{n}=$ male and female $)$ and |

$\mathrm{e}_{\mathrm{ijk} \mathrm{klmn}}=$ Random sampling error

\section{Results and Discussion}

The least squares means along with their standard errors for different milk production traits and the effects of various environmental factors on the traits analysed are in Table 1.

\section{Lactation length}

The mean lactation length of RCC was $259.6 \pm 6.2$ days, which is consistent with the studies of Habib et al. (2003) for RCC (261.1 \pm 14.5 days) at BAU dairy farm. Shorter lactations ( $211.5 \pm 20.9$ to $242.2 \pm 8.3$ days) were found by Alam et al. (2007); Munim et al. (2006); Khan et al. (1999) for RCC. Nondescript Desi cattle showed shorter lactation (221.3 \pm 21.9 to $250.6 \pm 69.8$ days) as reported by Khan et al. (2001); Rahman et al. (2001); Hossain and Routledge (1982). Longer lactations were reported by Hossain and Routledge (1982) for Pabna cows (286.0 \pm 67 days) and Munim et al. (2006) for local indigenous cattle (284.2 \pm 18.4 days). Their findings were not consistent with our study.

Table 1. Least squares means $( \pm \mathrm{SE})$ of milk production and their effects for various factors

\begin{tabular}{l|c|c|c|c|c|c}
\hline \multirow{1}{*}{ Traits } & Mean \pm SE & \multicolumn{5}{c}{ Level of significance } \\
\cline { 3 - 7 } & & $\begin{array}{c}\text { Sex of } \\
\text { calf born }\end{array}$ & $\begin{array}{c}\text { Lactation } \\
\text { order }\end{array}$ & $\begin{array}{c}\text { Season } \\
\text { of birth }\end{array}$ & $\begin{array}{c}\text { Year of } \\
\text { birth }\end{array}$ & $\begin{array}{c}\text { Calving } \\
\text { age }\end{array}$ \\
\hline Lactation length (day) & $259.6 \pm 6.2(100)$ & NS & NS & NS & NS & NS \\
Lactation yield (kg) & $500.7 \pm 19.3(103)$ & NS & $(\mathrm{P}<0.05)$ & NS & NS & $(\mathrm{P}<0.05)$ \\
$\begin{array}{lcccc}\text { Daily milk yield (kg) } \\
\text { Dry period (day) }\end{array}$ & $1.9 \pm 0.1(103)$ & NS & $(\mathrm{P}<0.05)$ & NS & $(\mathrm{P}<0.05)$ & NS \\
$\begin{array}{l}\text { Corrected lactation } \\
\text { yield (kg) }\end{array}$ & $605.4 \pm 22.9(103)$ & - & - & - & - & - \\
$\begin{array}{l}\text { Corrected 305-day } \\
\text { milk yield (kg) }\end{array}$ & $677.0 \pm 19.4(103)$ & - & - & - & - & - \\
$\begin{array}{l}\text { Corrected daily milk } \\
\text { yield (kg) }\end{array}$ & $2.2 \pm 0.1(103)$ & - & - & - & - & - \\
\hline
\end{tabular}

Figures in parenthesis indicate number of observations, NS means non-significant at $5 \%$ level (P>0.05); - Indicates effect not included in the model

Table 2 shows that cow that gave birth to male calves had a tendency to longer lactation, although it was statistically insignificant $(\mathrm{P}>0.05)$. Analysis of variance showed non-significant $(\mathrm{P}>0.05)$ variations of lactation length by lactation order, season of calving and year of calving. The longest lactation was at $4^{\text {th }}$ to $5^{\text {th }}$ lactation and minimum at $6^{\text {th }}$ lactation (not significant). The result is in agreement with the 
results of Cilek (2009); Zafar et al. (2008); Erdem et al. (2007); Bilgic and Alic (2005); Pelister et al. (2000a); Wilson et al. (1987), but not with the results of Cilek (2009); Zambrano et al. (2006), who found significant effects $(\mathrm{P}<0.05 ; \mathrm{P}<0.001)$ of lactation order and calving year on lactation duration. Age of cow did not significantly $(\mathrm{P}>0.05)$ affect lactation length (Table 1$)$ is in accordance with the results of Cilek (2009) but not with those of Inci et al. (2007); Pelister et al. (2000a).

\section{Lactation yield}

The mean lactation yield was $500.7 \pm 19.3 \mathrm{~kg}$. The result is closely in accordance with the results of Alam et al. (2007) and Munim et al. (2006) who found $516.9 \pm 35.9$ and $528.8 \pm 59.8 \mathrm{~kg}$ for RCC and Local $\times$ Sahiwal cross, respectively. But Munim et al. (2006); Habib et al. (2003) found better lactation yields of RCC as $570.5 \pm 112.5$ and $661.2 \pm 39.8 \mathrm{~kg}$, respectively. The lactation yield of RCC is better than that of nondescript Desi cows (213.0 $\pm 9 \mathrm{~kg})$ reported by Hossain and Routledge (1982). In study by Hossain and Routledge (1982), lactation yields was $803.0 \pm 290 \mathrm{~kg}$ for Pabna cows, higher than this study. The mean age-season corrected lactation yield and projected 305-day milk yield of RCC were $605.4 \pm 22.9$ and $677.0 \pm 19.4 \mathrm{~kg}$, respectively. There is no literature on RCC or other indigenous cows in Bangladesh for age-season corrected milk yield traits.

Analysis of variance revealed that milk yield is significantly $(\mathrm{P}<0.05)$ affected by lactation order and age at calving (Table 1). Milk yield reached a maximum at $5^{\text {th }}$ lactation and then declined (Table 2). Wilson et al. (1987) found yields increased to a maximum at $3^{\text {rd }}$ to $5^{\text {th }}$ lactations and then diminished. Zafar et al. (2008) found lowest milk yield for the first lactation and highest in $6^{\text {th }}$ lactation. Aslam et al. (2002) found highest milk yield in $4^{\text {th }}$ parity. Their results are closely in line with the result of this study. Many studies have found significant effect of parity (lactation number) on production, especially between first and later parities. This indicates that cows starting lactation at early age are not mature. But the result of this study contradicts the results of Alam et al. (2007); Bilgic and Alic (2005); Habib et al. (2003) who found non-significant effect of lactation number on yields. The present result is in agreement with the results of Cilek et al. (2009); Acharya et al. (1977), who reported cows attained highest yield at 7-7.5 years of age. Lactation yield was not affected significantly ( $\mathrm{P}>0.05)$ by sex of calf born, calving season and year (Table 1$)$. The small variations of milk yield with season and year of calving might be due to seasonal influences as well as feed, temperature, humidity and management. This statement is supported by Cilek (2009); Zafar et al. (2008); Cilek and Tekin (2005); Erdem et al. (2007); Aslam et al. (2002); Wilson et al. (1987), who reported significant variation of milk yield with those factors. Bilgic and Alic (2005); Pelister et al. (2000b); Wilson et al. (1987) reported milk yield was not affected significantly by those factors, in accordance with the present finding.

Daily milk yield

The mean daily milk yield of RCC was $1.9 \pm 0.1 \mathrm{~kg}$, similar to the study of Khan et al. (1999) who found daily milk yield of RCC to be $1.8 \pm 0.9$ and $2.0 \pm 0.7 \mathrm{~kg}$ for 
RCC in rural and farm conditions, respectively. Khan et al. (2001) found daily milk yield of nondescript Desi cows to be $1.9 \pm 0.3 \mathrm{~kg}$, similar to this study, but the result is inconsistent with Munim et al. (2006); Habib et al. (2003) who found $2.5 \pm 0.3$ and $2.6 \pm$ $0.1 \mathrm{~kg}$, respectively, for RCC. The daily milk yield of RCC is better than that of nondescript Desi cows as reported by Bhuiyan and Faruque (1993); Husain and Mostafa (1985), who found daily milk yield as $1.6 \pm 0.7$ and $1.5 \pm 0.2 \mathrm{~kg}(1.2 \pm 0.1 \mathrm{~kg}$ for farming condition), respectively. The standardized age and season corrected daily milk yield of RCC was estimated as $2.2 \pm 0.1 \mathrm{~kg}$.

Daily milk yield differed significantly $(\mathrm{P}<0.05)$ with lactation order and calving year (Table 1). The daily milk yield in $5^{\text {th }}$ lactation was significantly higher than in first lactation. This result is consistent with Munim et al. (2006) who found significant $(\mathrm{P}<0.05)$ effect of parity on daily milk yield. They reported higher average daily milk yield in $5^{\text {th }}$ parity than $1^{\text {st }}, 2^{\text {nd }}, 3^{\text {rd }}$, and $6^{\text {th }}$ parities. But the result differed from that of Habib et al. (2003) who found non-significant $(P>0.05)$ effect of lactation number on daily milk yield. Daily milk yield did not differ significantly $(\mathrm{P}>0.05)$ with sex of calf born, season and age at calving.

\section{Dry period}

This is the period of cessation of milk production. This trait is important to the dairyman. The average dry period in this study was $162.4 \pm 7.7$ days, which is close to the result obtained by Alam et al. (1994) who found 178.3 days in nondescript Desi cows. In contrast, Ali et al. (2006) found $134.3 \pm 37.3$ days dry period for indigenous cow. Longer dry periods ( $222.0 \pm 13.4$ to $275.0 \pm 13.6$ days) were obtained by Hossain and Routledge (1982) for nondescript Desi cows and Pabna cows, respectively.

Table 2 shows that dry period in $6^{\text {th }}$ parity was significantly $(\mathrm{P}>0.05)$ longer than in earlier parities. Cilek (2009); Zafar et al. (2008); Aslam et al. (2002) found lowest and highest dry period during $9^{\text {th }}$ and $1^{\text {st }}$ lactation, respectively. Erdem et al. (2007) and Inci et al. (2007) found non-significant effect of lactation number on dry period. Analysis of variance showed insignificant $(\mathrm{P}>0.05)$ difference of dry period with sex of calf born, season, year and age at calving (Table 1). This is in agreement with the results of Pelister et al. (2000a) for the effect of season of calving and Inci et al. (2007) for the effect of calving year, but Erdem et al. (2007); Zambrano et al. (2006); Bilgic and Alic (2005); Pelister et al. (2000a) found significant variations of dry period with calving year and age at calving. The variations in results by different authors might be due to different breed, feeding, management, or environment.

In conclusion, though milk productions of crossbred cows in Bangladesh are better than RCC, this study revealed better performance of RCC than other nondescript indigenous cattle of Bangladesh. Furthermore, the results clearly indicated that some non-genetic factors greatly affect milk production. No emphasis has been made for the improvement of RCC. Therefore, there is a need for a genetic improvement programme in RCC in order to make smallholder dairy farming more profitable in Bangladesh. 
Table 2. Mean milk yield traits and environmental factors

\begin{tabular}{|c|c|c|c|c|}
\hline \multirow[t]{2}{*}{ Factors } & \multicolumn{4}{|c|}{ Mean \pm SE } \\
\hline & $\begin{array}{c}\text { Lactation length } \\
\text { (days) }\end{array}$ & Lactation yield $(\mathrm{kg})$ & $\begin{array}{c}\text { Daily milk yield } \\
(\mathrm{kg})\end{array}$ & Dry period (days) \\
\hline Sex of calf born & NS & NS & NS & NS \\
\hline Male & $266.2 \pm 8.2(51)$ & $518.9 \pm 26.3(53)$ & $1.9^{a} \pm 0.1(53)$ & $163.8 \pm 1.5(36)$ \\
\hline Female & $252.8 \pm 9.4(49)$ & $481.4 \pm 28.4(50)$ & $1.9 \mathrm{a} \pm 0.1(50)$ & $160.7 \pm 10.0(30)$ \\
\hline Lactation order & NS & $P<0.05$ & $P<0.05$ & $P<0.05$ \\
\hline 1 & $239.7 \pm 14.4$ & $422.3^{b} \pm 39.5(25)$ & $1.7 \mathrm{~b} \pm .1 .0(25)$ & $168.9 \mathrm{a} \pm 18.4(15)$ \\
\hline 2 & $269.0 \pm 15.3(21)$ & $485.7 \mathrm{ab} \pm 35.0(21)$ & $1.79 \mathrm{ab} \pm 0.7(21)$ & $148.9 a \pm 14.6(13)$ \\
\hline 3 & $252.1 \pm 9.0(21)$ & $509.2^{\mathrm{ab}} \pm 30.5(21)$ & $2.02^{\mathrm{ab}} \pm 0.9(21)$ & $161.0^{\mathrm{a}} \pm 11.8(15)$ \\
\hline 4 & $276.6 \pm 12.3(16)$ & $564.4^{\mathrm{ab}} \pm 52.6(17)$ & $1.97 \mathrm{ab} \pm 1.5(17)$ & $138.7 \mathrm{a} \pm 12.7(14)$ \\
\hline 5 & $279.6 \pm 20.3(14)$ & $604.3^{a} \pm 69.3(14)$ & $2.17 \mathrm{a} \pm 1.8(14)$ & $192.3^{a} \pm 32.4(7)$ \\
\hline 6 & $231.5 \pm 8.9(4)$ & $413.8^{b} \pm 41.2(5)$ & $1.62^{\mathrm{b}} \pm 1.9(5)$ & $273.5^{\mathrm{b}} \pm 46.5(2)$ \\
\hline Calving season & NS & NS & NS & NS \\
\hline Summer & $247.8 \pm 9.8(31)$ & $492.3 \pm 34.0(33)$ & $1.9 \pm 1.0(33)$ & $181.9 \pm 16.7(15)$ \\
\hline Rainy & $256.9 \pm 12.7(31)$ & $486.1 \pm 31.8(31)$ & $1.9 \pm 0.9(31)$ & $157.6 \pm 13.0(20)$ \\
\hline Winter & $271.5 \pm 9.8(38)$ & $271.5 \pm 9.8(38)$ & $1.8 \pm 0.8(39)$ & $156.1 \pm 11.5(31)$ \\
\hline Calving year & NS & NS & $P<0.05$ & NS \\
\hline 2005 & $234.1^{\mathrm{a}} \pm 15.0(12)$ & $439.3^{b} \pm 45.0(12)$ & $1.9^{\mathrm{ab}} \pm 1.4(12)$ & $160.6 \pm 13.8(11)$ \\
\hline 2006 & $275.2^{\mathrm{ab}} \pm 10.1(25)$ & $588.9 a \pm 39.3(25)$ & $2.1^{\mathrm{a}} \pm 0.1(25)$ & $143.2 \pm 13.3(20)$ \\
\hline 2007 & $277.5^{b} \pm 16.4(23)$ & $473.2^{\mathrm{ab}} \pm 30.0(24)$ & $1.7 \mathrm{~b} \pm 0.7(24)$ & $163.0 \pm 16.3(18)$ \\
\hline 2008 & $259.8^{\mathrm{ab}} \pm 13.9$ & $492.4^{\mathrm{ab}} \pm 48.1(23)$ & $1.8^{\mathrm{ab}} \pm 1.2(23)$ & $187.8 \pm 16.5(16)$ \\
\hline 2009 & $233.5^{\mathrm{a}} \pm 11.2(19)$ & $468.4^{\mathrm{ab}} \pm 47.7(19)$ & $1.9 \mathrm{ab} \pm 1.4(19)$ & $152.00(1)$ \\
\hline Age at calving & NS & $\mathrm{P}<0.05$ & NS & NS \\
\hline$<4$ years & $254.2 \pm 12.4(27)$ & $460.79 \mathrm{ab} \pm 35.5(27)$ & $1.9 \mathrm{ab} \pm 0.9(27)$ & $162.4 \pm 14.4(18)$ \\
\hline $4-5$ & $241.5 \pm 14.5(24)$ & $417.37 \mathrm{~b} \pm 31.0(25)$ & $1.7^{b} \pm 0.7(25)$ & $154.0 \pm 13.0(18)$ \\
\hline $5-6$ & $266.6 \pm 8.9(23)$ & $555.99 a \pm 28.9(24)$ & $2.1^{\mathrm{a}} \pm 0.9(24)$ & $155.4 \pm 12.5(15)$ \\
\hline $6-7$ & $276.9 \pm 16.8(15)$ & $576.82^{a} \pm 60.5(15)$ & $2.1^{a} \pm 1.6(15)$ & $162.9 \pm 24.7(9)$ \\
\hline$>7$ & $274.5 \pm 20.1(11)$ & $558.6^{a} \pm 78.2(12)$ & $2.0^{\mathrm{ab}} \pm 0.2(12)$ & $204.7 \pm 39.9(6)$ \\
\hline
\end{tabular}

Figures in the parenthesis indicate number of observations, NS means non-significant at $5 \%$ level $(\mathrm{P}>0.05)$. Means with different superscripts within the same column differ significantly $(\mathrm{P}<0.05)$

\section{Acknowledgements}

The authors would like to thank USDA for funding Red Chittagong Cattle Project at BAU, Mymensingh which provided the facilities for this study.

\section{References}

Acharya RM, DS Balaine DS, Mohan M 1977: Genetic analysis of a closed herd of Hariana cattle. Indian Council of Agricultural Research, New Delhi, India pp. 9. 
| Alam M, Bhuiyan AKFH, Ali A, Mamun A 2007: Genetic analysis of birth weight and milk production of Red Chittagong cattle of Bangladesh. Bangladesh Journal of Animal Science 36 24-32.

Alam J, Akteruzzaman M, Rahman A, Ahmed Z 1994: Comparative performance of Local and Crossbred cows in Bangladesh. Indian Journal of Dairy Science 47 112-117.

Ali MH, Islam MN, Khan MAS, Islam MN 2006: Reproductive performance of different crossbred and indigenous dairy cows at Takerhat milk shed area, under the Bangladesh Milk Producers' co-operative union limited (Milk Vita). Journal of Bangladesh Society of Agricultural Science and Technology 3 91-94.

Alpan O 1994: Breeding and feeding of cattle. Ph.D. Thesis, Selcuk University, the Institute for Health Sciences, Ankara, Konya, Turkey pp. 5-57.

Aslam M, Nawaz M, Khan MS 2002: Comparative performance of some cattle breeds under Barani conditions of Pakistan. International Journal of Agriculture and Biology 4 565-567.

Bhuiyan AKFH, Faruque MO 1993: Yield and variability of milk production in Local Cattle of Bangladesh. Proceeding of the Bangladesh Agricultural University Research System (BAURES) Workshop, Mymensingh pp. 1-5.

Bilgic N, Alic D 2005: Milk yield traits of Holstein Friesian cows raised in polatli state farm. In: Faculty of Agriculture, Sabanc1 University 19 116-119.

Cilek S 2009: Milk yield traits of Holstein cows rose at Polatli State Farm in Turkey. Journal of Animal and Veterinary Advances 8 6-10.

Cilek S, Tekin ME 2005: The environmental factors effecting milk yield and fertility traits of Simmental cattle rose at Kazova State Farm and phenotypic correlations between these traits. Turkish Journal of Veterinary and Animal Science 29 987-993.

Erdem H, Atasever S, Kul E 2007: Milk yield and fertility traits of Holstein cows raised at Gokhoyuk State farm, 1. Milk Yield Traits. Journal of Faculty of Agriculture, subtitle 22 41-46.

Habib MA, Bhuiyan AKFH, Bhuiyan MSA, Khan AA 2003: Performance of Red Chittagong Cattle in Bangladesh Agricultural University Dairy Farm. Bangladesh Journal of Animal Science 32 101-108.

Hossain MA, SF Routledge 1982: Performance of crossbred and local cattle under village conditions in Pabna district of Bangladesh. In: Proceeding of 'Maximum Livestock Production from Minimum Land' Seminar paper pp. 161-167.

Husain SS, Mostafa KG 1985: Reproductive potentialities of Local and Crossbred animals under farm and village conditions. Livestock Adviser 10 15-19.

Inci S, Kaygisiz, A, Efe E, Bas S 2007: Milk yield and reproductive traits in brown swiss cattle raised at Altinova State Farm, Ankara University. Journal of Agricultural Sciences 13 203-212.

Khan MS, Islam MN, Hashem MA, Sultana Z 2001: Milk production performance of Indigenous and Crossbred cows of private dairy farm. Bangladesh Journal of Animal Science 30 15-19. 
Khan AA, Ali A, Husain SS, Bhuiyan AKFH 1999: Reproductive performances of different genetic group of cows under farm condition. Bangladesh Journal of Animal Science 28 59-64.

Munim T, Hussain SS, Hoque MA, Khandoker MAMY 2006: Genetic and non-genetic effects on productive and reproductive traits of different genetic groups of cows. Bangladesh Journal of Animal Science 35 1-12.

Pelister B, Altinel A, Gunes H 2000a: An investigation on the milk yield characteristics of black pied cattle of different origin in commercial farm conditions. Istanbul University Veterinary Faculty Journal 26 201-214.

Pelister B, Altinel A, Gunes H 2000b: An investigation on the milk yield characteristics of Holstein cattle of different origin in commercial farm condition. Istanbul University Veterinary Faculty Journal 26 543-556.

Rahman MM, Khan MAS, Islam MN, Haque MN, Sarker MSK 2001: Genetic differences in the performance of Local, Pure and Crossbred cows. Bangladesh Journal of Animal Science 30 155-164.

Van Vleck LD, Henderson CR 1961: Ratio factors for adjusting monthly test-day data for age and season of calving and ratio factors for extending part lactation records. Journal of Dairy Science 44 1093-1101.

Wilson RT, Ward PN, Saeed AMand Light D 1987: Milk production characteristics of the Kenana breed of Bos indicus cattle in Sudan. Journal of Dairy Science 70 2673-2679.

Zafar AH, Ahmad M, Rehman SU 2008: Study of some performance traits in Sahiwal | cows during different periods. Pakistan Veterinary Journal 28 84-88.

Zambrano S, Contreras G, Pirela M, Canas H, Olson T, Landaeta-Hernandez A 2006: Milk yield and reproductive performance of crossbred Holstein $\times$ Criollo Limonero cows. Science Magazine, Faculty of Veterinary Science, University of Zulia, Venezuela XVI 155-164. 